\author{
Krzysztof Blażejczyk \\ University of Warsaw, \\ Faculty of Geography and Regional Studies \\ Department of Climatology \\ e-mail: kblazejczyk@uw.edu.pl
}

\title{
ASSESSMENT OF REGIONAL BIOCLIMATIC CONTRASTS IN POLAND
}

\begin{abstract}
Traveling is one of most popular tourism activity. Usually it is associated with the change of climate conditions. In a short time we can move to different environment and our organisms are under great pressure of atmospheric stimuli which have diverse level and range of variability in comparison to home location. The general climate information seem to be insufficient to be prepared to new conditions. The paper presents new complex index which can be used to assess contrasts of bioclimatic conditions $(B C I)$. It was applied to compare differences in bioclimatic conditions in six stations represented various bioclimate regions of Poland: Koszalin (Coastal region), Białystok (North-East region), Warszawa and Wrocław (Central region), Rzeszów (South-East region) and Hala Gąsienicowa (Tatras, Carpathians region).
\end{abstract}

Key words: bioclimate differences, acclimatisation, bioclimatic index, bioclimatic stress

\section{INTRODUCTION}

For people travelling for long distances very important is information about climate contrasts they can experience in particular destinations in comparison to home location. Their organism must adapt to new climate stimuli. At several researches adaptation strategies of human organism to varying atmospheric stimuli are discussed (Jendritzky, Dear 2008). The special attention is paid for keeping homeothermy, i.e. constant core temperature (about $37^{\circ} \mathrm{C}$ ) in varying thermal environment. In particular ranges of ambient temperature various acclimation processes play leading role (Broede et al. 2011, Table 1).

In cold environments all physiological efforts of an organism lead to minimise heat loss from the body. The centre of thermoregulation reduce skin blood flow which results in decrease of skin temperature and increase in thermoinsulative properties of skin (Blanc 1975; Clark, Edholm 1985). Additionally, muscles produce heat by shivering thermogenesis (Fiala et al. 1999, 2001). The autonomic mechanisms of temperature regulation are usually supported by behavioral thermoregulation, mostly by using of well insulative clothing (Holmér 1988; ISO/DC 11079). 
Table 1. Predominant physiological reactions of an organism in various thermal environments

\begin{tabular}{|c|c|c|c|c|c|}
\hline $\begin{array}{c}\text { Thermal } \\
\text { conditions: }\end{array}$ & $\begin{array}{l}\text { Extreme } \\
\text { cold }\end{array}$ & Cold & Moderate & Heat & $\begin{array}{c}\text { Extreme } \\
\text { heat }\end{array}$ \\
\hline $\begin{array}{l}\text { Physiological } \\
\text { reactions }\end{array}$ & $\begin{array}{l}\text { - core temp. } \\
\text { - local skin } \\
\text { tempera- } \\
\text { ture } \\
\text { - shivering }\end{array}$ & $\begin{array}{l}\text { - skin tem- } \\
\text { perature } \\
\text { - shivering }\end{array}$ & $\begin{aligned} & \text { blood flow } \\
\text { - } & \text { skin tem- } \\
& \text { perature }\end{aligned}$ & $\begin{array}{l}\text { - skin blood flow } \\
\text { - cardiac output } \\
\text { - skin temperature } \\
\text { - sweat rate } \\
\text { - skin wettedness } \\
\text { - core temperature }\end{array}$ & $\begin{array}{l}\text { - } \text { core tem- } \\
\text { perature } \\
\text { - } \text { sweat rate }\end{array}$ \\
\hline
\end{tabular}

Source: Broede et al. 2011

In hot conditions physiological processes lead to intensive expenditure of heat from the body. The most important is increasing of skin blood flow. It resulted both, in activation of sweat glands and in intensifying of cardiac output (Beaumont, Bullard 1965; Garden et.al. 1966; Givoni, Goldman 1973). Evaporation of sweat reduce risk of body overheating (Kenney 1985). However, it also lead to disturbances in water and mineral balances of an organism (Błażejczyk, Szygula 2004).

In spite of relatively good knowledge of thermal adaptation mechanisms there are only few attempts to find objective, quantitative method of assessing bioclimatic contrasts of particular areas and/or seasons. One of the first is concept of Bioclimatic Distance index proposed by Mateeva and Filipov (2003). The index bases on comparison of effective clothing insulation (ECI) necessary for keeping balance between heat gains and heat losses in the human body. ECI is calculated by MENEX human heat balance model (Blazejczyk 2001) taking constant skin temperature of $32^{\circ} \mathrm{C}$. The $B D$ index is calculated as follows:

$$
B D=\left(E C I_{\mathrm{h}}-E C I_{\mathrm{d}}\right) / 13 \cdot 100
$$

where numerical coefficient 13 is expressed in clo and it represents maximal ECI difference.

The authors successfully used $B D$ index for climatic conditions of Balkan Peninsula using mean monthly meteorological data. However, when trying to use $B D$ to more differentiated climate conditions and for daily meteorological data several problems arise. Firstly, for specific combinations of meteorological variables the balancing of heat gains and heat losses by changing of clothing insulation is impossible. Secondly, for specific situations calculated ECI obtain unrealistic values (e.g. 45 clo). Additional weakness of $B D$ index is using only one measure of heat stress which is important in cold environments.

De Freitas and Grigorieva (2009, 2010) propose Acclimatization Thermal Strain Index (ATSI). It bases on the Rusanov (1989) concept of heat loss by respiration used to assess bioclimatic conditions at Siberia region. ATSI index considers heat loss by respiration at home location $\left(\operatorname{Res}_{\mathrm{h}}\right)$ and at studied destination $\left(\operatorname{Res}_{\mathrm{d}}\right)$ and is calculated as follows: 


$$
A T S I=\left(\operatorname{Res}_{\mathrm{h}}-\operatorname{Res}_{\mathrm{d}}\right) / \operatorname{Res}_{\mathrm{h}} \cdot 100
$$

The authors successfully used ATSI for bioclimatic assessment of Russian Far East. The greatest weakness of such index is using respiration at home location as reference value. Such assumption leads to great differences in ATSI when considering various home locations. It can be used only for assessing adaptation stress when traveling one way. Additionally, respiratory heat loss is physiological measure of heat stress important only in cold climates. Thus, usefulness of ATSI for general bioclimatic comparisons is limited.

Taking into consideration weaknesses of existing methods the aim of this paper is to present new, complex index of bioclimatic contrasts (BCI Bioclimatic Contrast Index). It was applied to assess bioclimatic contrasts between particular locations in Poland, represented various bioclimatic regions.

\section{METHODS AND MATERIALS}

Bioclimatic Contrast Index (BCI) consists of various measures used for validation of bioclimatic conditions. The applied measures represent whole range of thermal environments. Water Loss $(S W)$ is a measure of adaptation to hot environments, Insulation Predicted (Iclp) represents acclimation stress in cold conditions. Physiological Subjective Temperature (PST) is a measure of thermal sensations caused by actual weather conditions. However, Universal Thermal Climate Index (UTCI) represents intensity of heat stress in wide range of environmental conditions. BioKlima 2.6 software package was used for the calculations of all indices (www.igipz.pan.pl/geoekoklimat/ blaz/bioklima.htm).

Water loss from the skin due to water diffusion and sweating $(S W$, in $\mathrm{g} \cdot$ hour $\left.^{-1}\right)$ is calculated for actual thermal and wind conditions assuming relative air humidity equal to $5 \%$ and metabolic heat production of $135 \mathrm{~W} \cdot \mathrm{m}^{-2}$ using the following equation (Blazejczyk 2007, 2010):

$$
S W=-2.6 \cdot\left[h e \cdot\left(v p_{5}-v p_{s k}\right) \cdot w \cdot I e-27.3\right]
$$

For explanations of variables see Annex 1.

Insulation Predicted (Iclp, in clo) gather two approaches: Burton and Edholm (1955) concept for assessing total insulation of clothing and surrounding air layer $\left(I_{t o t}\right)$ as well as Fourt and Hollies (1970) equation of insulation of air layer $\left(I_{\alpha}\right)$ :

$$
I c l p=I_{t o t}-I_{a}
$$

where: $\quad I_{t o t}=0.082 \cdot[91.4-(1.8 \cdot t+32)] / 2.3274$, $I_{a}=\left[1 /\left(0.61+1.9 \cdot v^{0.5}\right)\right]$. 
Physiological Subjective Temperature $(P S T)$ is derived from the MENEX_2005 human heat balance model (Blazejczyk 2007, Błażejczyk, Matzarakis 2007) and it represents subjective feeling of the thermal environment by persons after $20 \mathrm{~min}$ of adaptation to ambient conditions. The following equations are used for the calculations:

$$
\begin{aligned}
& P S T=i M r t-\left\{\left[|S r|^{0.75} /\left(0.95 \cdot 5.667 \cdot 10^{-8}\right)+273^{4}\right]^{0.25}-273\right\}\left(\text { for } S r<0 \mathrm{~W} \cdot \mathrm{m}^{-2}\right), \\
& P S T=i M r t+\left\{\left[|S r|^{0.75}\left(0.95 \cdot 5.667 \cdot 10^{-8}\right)+273^{4}\right]^{0.25}-273\right\}\left(\text { for } S r>=0 \mathrm{~W} \cdot \mathrm{m}^{-2}\right)
\end{aligned}
$$

The UTCI is defined as the air temperature $(t)$ of the reference conditions causing the same physiological response as the actual weather condition (Blazejczyk et al., 2010; Broede et al., 2011). The UTCI is a one-dimensional quantity which adequately reflects the human physiological reaction to the multi-dimensionally defined actual thermal condition. Both, meteorological and non-meteorological (metabolic rate and thermal resistance of clothing) reference conditions were defined: a wind speed of $0.5 \mathrm{~m} / \mathrm{s}$ at $10 \mathrm{~m}$ height, a mean radiant temperature equal to air temperature and vapour pressure that represent relative humidity of $50 \%$ (at air temperatures $>29^{\circ} \mathrm{C}$ the reference humidity was taken constant at $20 \mathrm{hPa}$ ). A representative activity (135 $\left.\mathrm{W} \cdot \mathrm{m}^{-2}\right)$ to be that of a person walking with a speed of $4 \mathrm{~km} / \mathrm{h}(1.1 \mathrm{~m} / \mathrm{s})$.

In routine applications $U T C I$ can be calculated using an approximating regression polynomial function up to $6^{\text {th }}$ order. The least square estimates of the 210 coefficients were found (Blazejczyk et al., 2010, Broede et al., 2011).

$$
U T C I=f(t, v p, v, \mathrm{~d} M r t) .
$$

The Bioclimatic Contrast Index is averaged difference of used indicators of adaptation to climate: SW, Iclp, PST and UTCI. The general equation of $B C I$ has the following form:

$$
B C I=(\mathrm{d} U T C I+\mathrm{d} S W+\mathrm{d} I c l p+\mathrm{d} P S T / 4
$$

where:

$$
\mathrm{d} U T C I=\left(U T C I_{\mathrm{h}}-U T C I_{\mathrm{d}}\right) / 170 \cdot 100
$$

$\left(170\right.$, in ${ }^{\circ} \mathrm{C}$, is possible range of $\left.U T C I\right)$,

$$
\mathrm{d} S W=\left(S W_{\mathrm{h}}-S W_{\mathrm{d}}\right) / 1000 \cdot 100
$$

(1000, in g/hour, refers to maximum effectiveness of sweat glands),

$$
\mathrm{d} I c l p=\left(I c l p_{\mathrm{d}}-I c l p_{\mathrm{h}}\right) / 7 \cdot 100
$$

(7, in clo, is a possible range of clothing insulation), 


$$
\mathrm{d} P S T=\left(P S T_{\mathrm{h}}-P S T_{\mathrm{d}}\right) / 110 \cdot 100
$$

$\left(110\right.$, in ${ }^{\circ} \mathrm{C}$, is possible range of $\left.P S T\right)$.

Positive values of $B C I$ and its components indicate „warmer" conditions at home location then at chosen destination. However, increase of absolute values of indicators illustrates increase in intensity of adaptation processes in an organism, and consequently they tell about rising contrasts of bioclimatic conditions. The particular ranges of absolute values of $B C I$ can be assessed as follows:

$\begin{array}{ll}|B C I| & \text { Bioclimatic contrasts } \\ \leq 5,0 & \text { - insignificant } \\ 5,1-10,0 & \text { - small } \\ 10,1-20,0 & \text { - significant } \\ 20,1-30,0 & \text { - great } \\ 30,1-50,0 & \text { - very great } \\ >50,0 & \text { - extreme }\end{array}$
Adaptation intensity slight adaptation moderate adaptation intensive adaptation increased adaptation very intensive adaptation extremely intensive adaptation

To validate $B C I$ daily meteorological data for 12:00 UTC for the period 1991-2000 were applied. The stations used in research represent various bioclimatic regions of Poland (Fig. 1, Błażejczyk, 2004): Koszalin (Coastal region), Białystok (North-East region), Warsaw and Wrocław (Central region), Rzeszów (South-East region) and Hala Gąsienicowa (Tatras, Carpathians region).

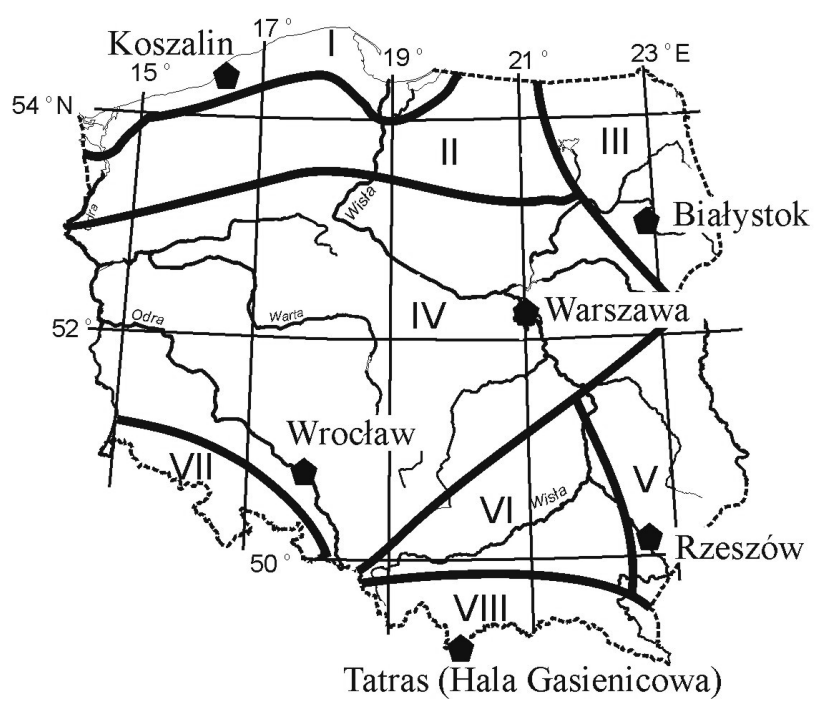

Fig. 1. Studied sites and their locations in bioclimatic regions of Poland: I - Coastal, II Lakeland, III - North-East, IV - Central, V - South-East, VI - Upland, VII - Sudetic, VIII - Carpathians 
To validate $B C I$ the bioclimatic contrasts were calculated for every pair of stations for each day of the studied period. BCI characteristics (mean, maximum, minimum values and frequency of particular ranges) were defined for consecutive decades of months.

\section{RESULTS}

Table 2 shows mean and maximum annual BCI values for studied stations' pairs. The largest mean bioclimatic contrasts were found for Tatra Mts. in comparison to other locations in Poland. The most intensive adaptation processes are necessary when traveling to Tatras from Rzeszów, Warszawa and Wrocław. Bioclimatic conditions in Coastal region (Koszalin) also differ significantly from other regions. The smallest differences are observed for Warszawa and Wrocław as well as for Warszawa and Białystok. In general, similar each other bioclimatic conditions occur in all lowland and upland regions of Poland (regions I - VI at figure 1).

Table 2. Mean and maximum annual bioclimatic contrasts between studied locations

\begin{tabular}{|c|c|c|c|c|c|c|c|}
\hline & \multicolumn{6}{|c|}{ Mean annual $B C I$ values } \\
\hline & & Koszalin & Białystok & Warszawa & Wrocław & Rzeszów & Tatras \\
\hline \multirow{6}{*}{ 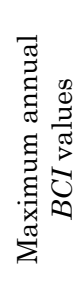 } & Koszalin & $\mathrm{x}$ & 15.0 & 14.8 & 13.5 & 17.4 & 21.6 \\
\hline & Białystok & 99.3 & $\mathrm{x}$ & 9.2 & 14.5 & 12.3 & 26.1 \\
\hline & Warszawa & 91.3 & 73.4 & $\mathrm{x}$ & 9.2 & 11.4 & 25.0 \\
\hline & Wrocław & 96.4 & 90.5 & 63.4 & $\mathrm{x}$ & 13.7 & 26.0 \\
\hline & Rzeszów & 100.8 & 80.7 & 87.3 & 92.8 & $\mathrm{x}$ & 26.5 \\
\hline & Tatras & 104.5 & 92.9 & 95.6 & 97.2 & 98.7 & $\mathrm{x}$ \\
\hline
\end{tabular}

The highest maximum $B C I$ values were found for Koszalin, represented Coastal region and for Hala Gasienicowa, represented Carpathian region. However, the smallest maximum bioclimatic contrasts were observed for Warszawa in comparison to Wrocław and Białystok.

When planning travels we must also consider seasonal differences in bioclimatic conditions. As seen at figure 2 the largest bioclimatic contrasts, both mean and maximum $B C I$ values, occur in warm period of the year (from May till September or even October). Such seasonal differentiation of bioclimatic contrasts are mostly observed at two destinations: coastal and mountain. In average, travels to those destinations from other regions can involve increased adaptation processes in human organisms.

In particular days maximum $B C I$ values can reach 90-100 which indicate extreme bioclimatic contrasts. They occur mostly in summer and are related to great differences in evaporative water loss, thermal sensations and heat stress. Coastal and mountain areas are considerably cooler and water loss 

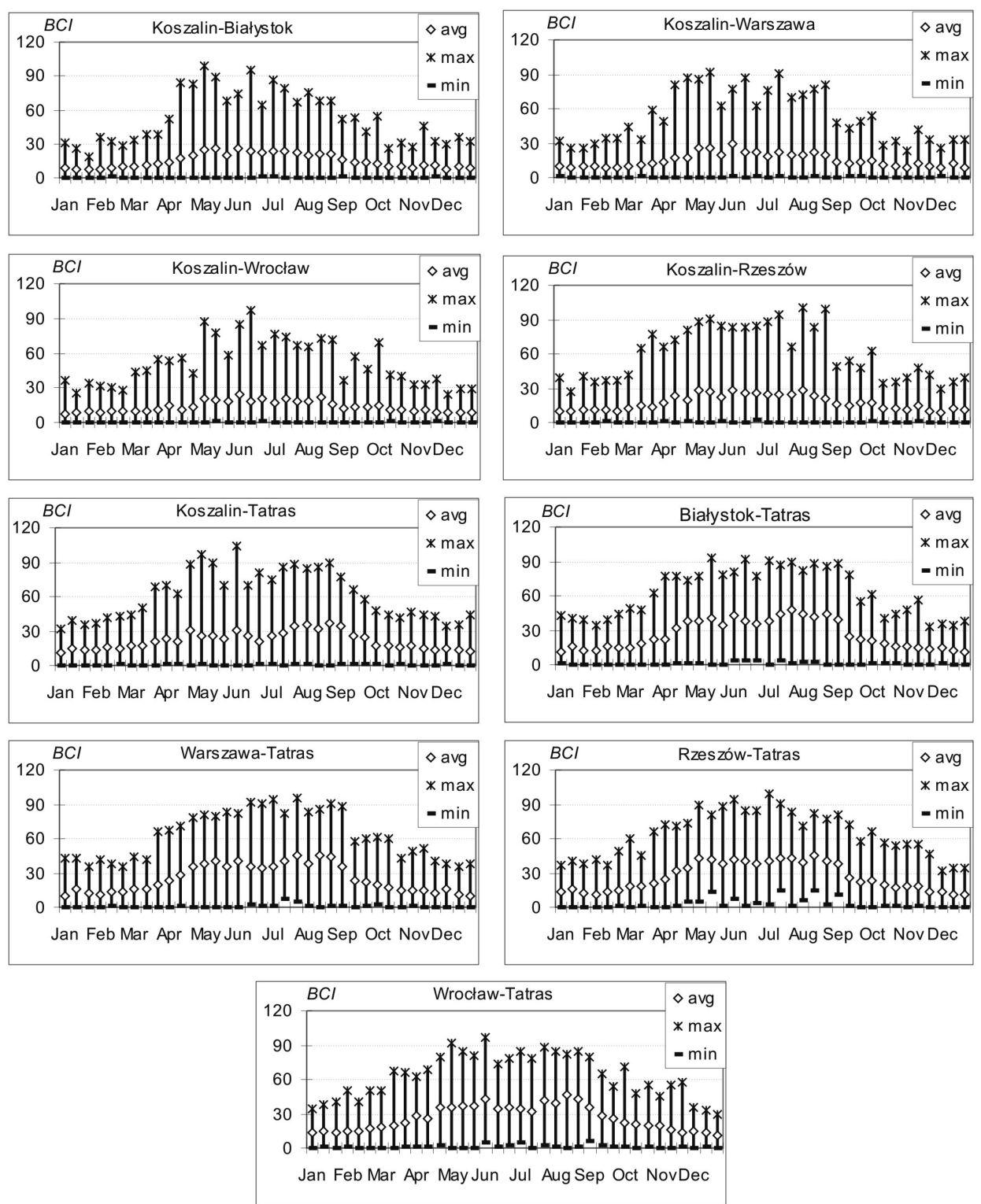

Fig. 2. Average (avg), maximum ( $\max$ ) and minimum (min) decadal values of $B C I$ for pairs of compared stations for coastal and mountain locations, 1996-2005

is there significantly smaller in comparison to another regions. In cold period (November to March or April) bioclimatic conditions in Coastal and Mountain regions do not differ from other areas of Poland.

Relatively great bioclimatic contrasts are observed when comparing northeast and south-east parts of Poland. When traveling from Białystok to 

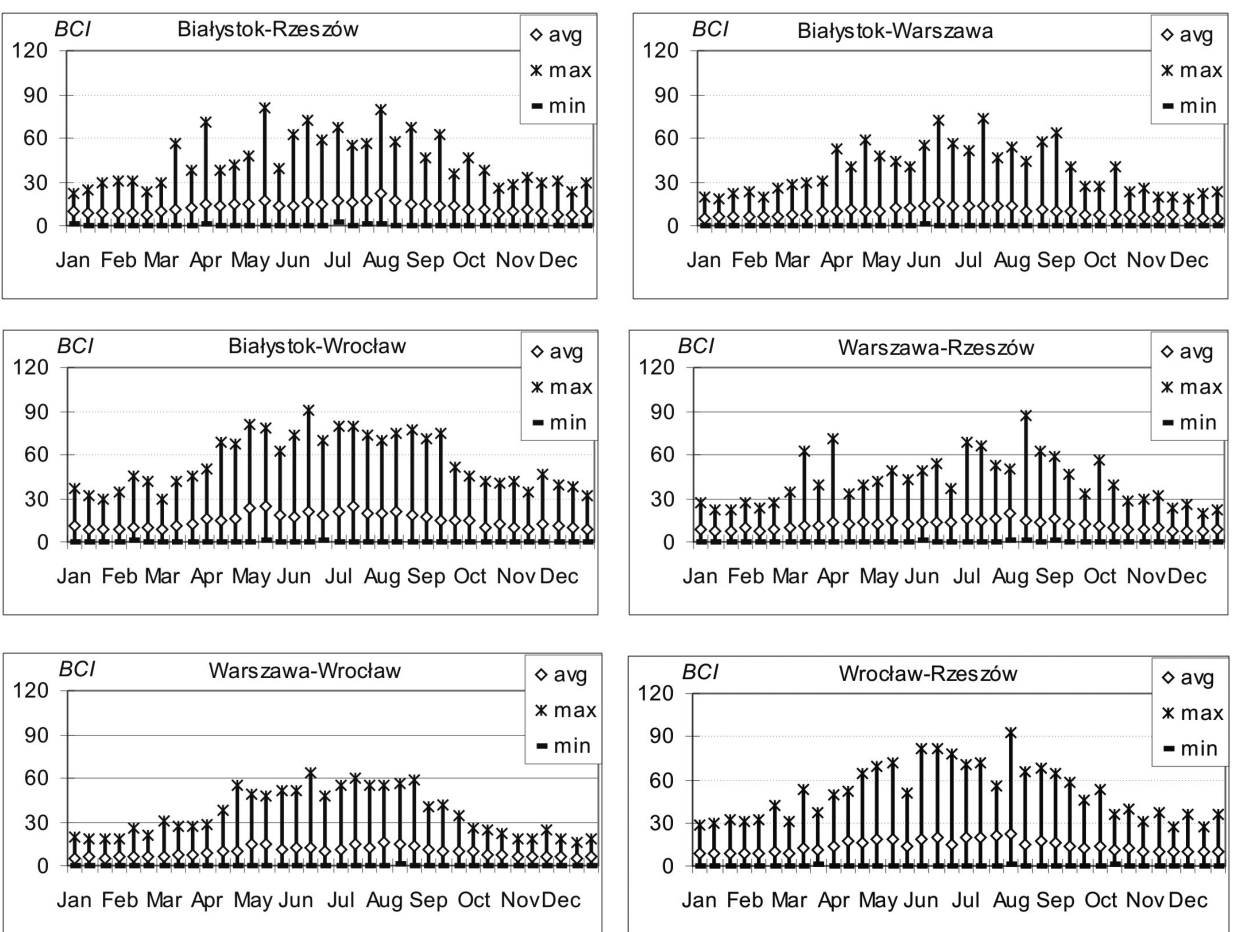

Fig. 3. Average (avg), maximum (max) and minimum (min) decadal values of $B C I$ for pairs of compared stations for lowland locations, 1996-2005

Wrocław people can experience similar adaptation stress like during travels to coastal and mountain locations. However, for nearer destinations, e.g. Warszawa-Białystok, Warszawa-Wrocław or Warszawa-Rzeszów, bioclimatic contrasts are in average small $(B C I$ of 5 -10) of at last significant (BCI of 10-20) (Fig. 3).

In bioclimatic analysis very important is also frequency of particular ranges of $B C I$ and the directions of adaptation processes. Tables 3 and 4 contain frequency of particular ranges of actual $B C I$ values between pairs of stations. Positive $B C I$ ranges indicate warmer conditions at home locations then at destination sites. And vice versa negative $B C I$ values tell us that destination represents warmer conditions in comparison to home location.

In general, for the whole year (Table 3) for the stations located outside mountain regions the most frequent are days with insignificant contrast of bioclimatic conditions. Such situations occur up to $37-38 \%$ days when traveling from Warszawa to Wrocław and from Warszawa to Białystok. During travels from lowland sites in Poland to Tatra Mts. we must be prepared for cooler conditions observed there in comparison to home locations. At almost half days of the year the contrasts are great or even more sever. Extremely 
cooler conditions occur at $13-15 \%$ days of the year. Traveling to coastal region from other cities in Poland is related with at last great bioclimatic contrasts at about $17-23 \%$ of days in the year.

Table 3. Frequency of particular ranges of $B C I$ values for particular pairs of stations

\begin{tabular}{|c|c|c|c|c|c|c|c|c|c|c|c|c|c|c|c|}
\hline$B C I$ range & 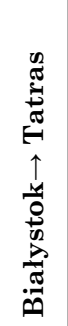 & 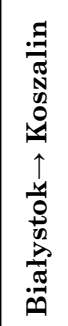 & 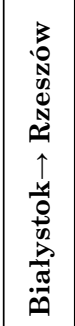 & 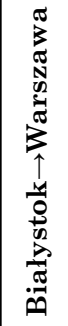 & 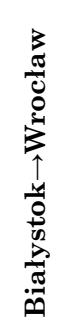 & 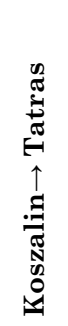 & 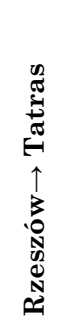 & 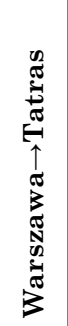 & 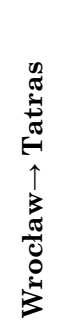 & 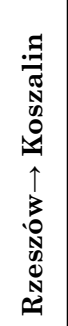 & 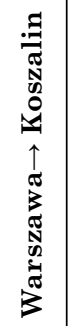 & 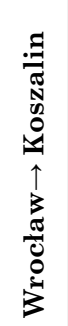 & 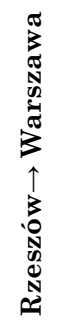 & 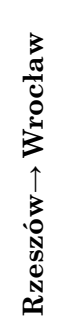 & 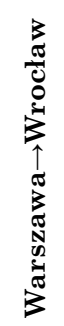 \\
\hline$-5.0-5.0$ & 11.4 & 22.7 & 28.2 & 38.2 & 26.0 & 15.5 & 10.3 & 12.3 & 10.7 & 19.9 & 23.5 & 26.6 & 30.1 & 25.7 & 37.1 \\
\hline$-5.1--10.0$ & 4.5 & 11.0 & 12.5 & 12.1 & 13.2 & 5.7 & 4.5 & 5.1 & 3.6 & 9.0 & 12.7 & 11.2 & 11.1 & 13.4 & 17.1 \\
\hline $5.1-10.0$ & 6.9 & 11.2 & 12.3 & 14.4 & 10.0 & 9.9 & 7.4 & 9.4 & 8.1 & 9.9 & 10.0 & 12.7 & 14.4 & 9.6 & 9.6 \\
\hline$-10.1--20.0$ & 5.9 & 14.8 & 15.4 & 12.3 & 16.5 & 5.7 & 4.8 & 5.4 & 4.8 & 14.2 & 15.0 & 10.2 & 11.9 & 16.0 & 14.1 \\
\hline $10.1-20.0$ & 18.5 & 13.2 & 11.6 & 12.0 & 10.4 & 20.5 & 18.0 & 18.7 & 19.5 & 14.2 & 13.0 & 16.2 & 15.0 & 12.1 & 10.3 \\
\hline$-20.1--30.0$ & 3.0 & 5.5 & 6.8 & 2.9 & 7.5 & 2.3 & 2.4 & 2.9 & 2.3 & 6.0 & 5.9 & 4.0 & 4.3 & 7.3 & 3.1 \\
\hline $20.1-30.0$ & 15.0 & 7.9 & 4.7 & 3.0 & 4.6 & 15.5 & 16.1 & 12.5 & 16.6 & 9.1 & 7.2 & 8.5 & 6.1 & 5.1 & 3.4 \\
\hline$-30.1--50.0$ & 1.3 & 2.1 & 3.4 & 1.1 & 3.8 & 0.6 & 0.7 & 1.3 & 0.7 & 2.8 & 2.3 & 1.0 & 2.2 & 3.4 & 1.1 \\
\hline $30.1-50.0$ & 18.7 & 7.0 & 3.2 & 2.4 & 3.8 & 16.7 & 21.8 & 18.9 & 20.3 & 9.5 & 5.8 & 6.5 & 3.4 & 4.6 & 2.3 \\
\hline$<-50.0$ & 0.0 & 0.0 & 0.7 & 0.1 & 1.0 & 0.6 & 0.4 & 0.4 & 0.4 & 0.7 & 1.0 & 1.1 & 0.1 & 0.2 & 0.1 \\
\hline$>50.0$ & 14.7 & 4.8 & 0.9 & 1.9 & 2.9 & 7.3 & 13.6 & 12.9 & 13.0 & 4.5 & 3.5 & 1.9 & 1.8 & 2.5 & 1.7 \\
\hline
\end{tabular}

$\rightarrow$ indicates direction of travel

In particular seasons the frequencies of various ranges of bioclimatic contrasts are very differentiated. In general, in winter (December-February) for majority of Poland insignificant contrasts predominate. When traveling to mountains or to the coastal area the contrast can be small or up to significant. Great or more sever contrasts can occur at 1 to $17 \%$ of winter days. In summer (June-August) at last great bioclimatic contrasts can be experienced at $70-80 \%$ of days when moved to Tatra Mts. We must be there prepared for significantly cooler conditions in comparison to our home location. High frequency (30-40\%) of cooler situations is also observed when moving to coastal resorts. During spring and autumn we can experience increased, very intensive or even extremely intensive adaptation to cold at $30-60 \%$ of days (Table 4). 
Table 4. Frequency of particular, aggregated ranges of $B C I$ values for particular pairs of stations

\begin{tabular}{|c|c|c|c|c|c|c|c|c|c|c|c|c|c|c|c|}
\hline$B C I$ range & 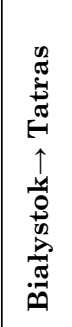 & 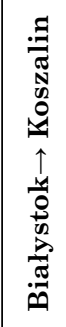 & 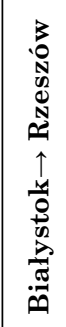 & 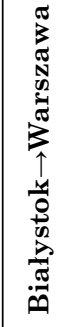 & 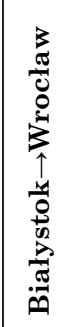 & 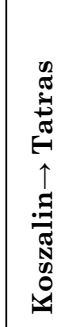 & 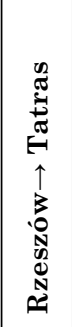 & 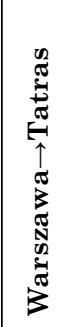 & 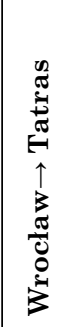 & 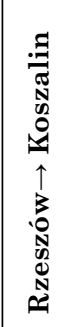 & 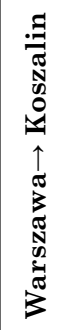 & 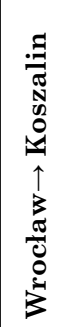 & 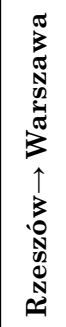 & 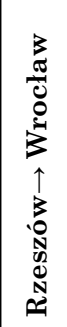 & 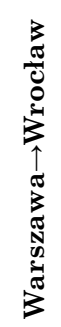 \\
\hline \multicolumn{16}{|c|}{ Winter } \\
\hline$-5.0-5.0$ & 20.6 & 29.9 & 37.4 & 47.6 & 40.3 & 24.6 & 21.7 & 21.5 & 21.5 & 28.7 & 30.3 & 33.0 & 41.1 & 35.5 & 46.8 \\
\hline$-5.1--20.0$ & 19.0 & 32.4 & 32.9 & 21.4 & 32.5 & 15.6 & 19.9 & 21.3 & 14.0 & 26.5 & 40.0 & 30.4 & 23.7 & 32.6 & 36.1 \\
\hline $5.1-20.0$ & 37.5 & 25.7 & 24.5 & 27.9 & 20.4 & 40.7 & 36.8 & 34.5 & 39.3 & 27.0 & 19.6 & 28.7 & 29.8 & 22.4 & 14.0 \\
\hline$<-20.0$ & 8.8 & 8.4 & 3.8 & 1.8 & 6.6 & 4.4 & 7.9 & 11.1 & 8.4 & 9.7 & 8.6 & 3.9 & 2.6 & 8.0 & 2.7 \\
\hline$>20.0$ & 14.0 & 3.5 & 1.4 & 1.3 & 0.3 & 14.8 & 13.6 & 11.5 & 16.8 & 8.1 & 1.6 & 4.1 & 2.8 & 1.6 & 0.4 \\
\hline \multicolumn{16}{|c|}{ Spring } \\
\hline$-5.0-5.0$ & 8.7 & 21.0 & 22.0 & 33.9 & 20.4 & 13.7 & 6.7 & 9.3 & 7.6 & 15.7 & 19.4 & 24.3 & 26.7 & 21.5 & 30.8 \\
\hline$-5.1--20.0$ & 9.0 & 19.6 & 27.1 & 26.7 & 27.4 & 13.0 & 8.7 & 9.6 & 11.4 & 21.3 & 21.7 & 19.6 & 24.0 & 28.6 & 29.3 \\
\hline $5.1-20.0$ & 20.7 & 24.9 & 24.9 & 24.3 & 20.4 & 26.3 & 19.1 & 23.4 & 20.8 & 21.7 & 26.2 & 29.2 & 27.6 & 20.3 & 22.0 \\
\hline$<-20.0$ & 4.1 & 8.5 & 12.4 & 3.9 & 13.5 & 4.9 & 4.0 & 3.6 & 2.9 & 10.5 & 12.0 & 7.5 & 7.6 & 10.9 & 4.7 \\
\hline$>20.0$ & 56.7 & 26.4 & 12.6 & 12.3 & 17.3 & 42.5 & 61.8 & 53.3 & 57.3 & 30.1 & 20.8 & 19.5 & 15.5 & 17.7 & 12.5 \\
\hline \multicolumn{16}{|c|}{ Summer } \\
\hline$-5.0-5.0$ & 3.1 & 13.3 & 23.3 & 30.3 & 16.9 & 8.3 & 0.9 & 3.5 & 3.6 & 12.5 & 17.7 & 19.3 & 21.8 & 20.3 & 28.5 \\
\hline$-5.1--20.0$ & 1.6 & 19.3 & 23.9 & 27.1 & 24.4 & 7.5 & 0.5 & 1.4 & 1.8 & 17.4 & 15.1 & 15.2 & 23.1 & 23.8 & 27.9 \\
\hline $5.1-20.0$ & 11.2 & 22.5 & 21.4 & 22.1 & 21.0 & 24.0 & 11.3 & 17.7 & 17.3 & 21.3 & 23.0 & 26.2 & 26.1 & 20.8 & 22.8 \\
\hline$<-20.0$ & 0.9 & 5.8 & 15.8 & 7.9 & 16.2 & 2.5 & 0.0 & 0.2 & 0.5 & 9.0 & 7.7 & 6.2 & 12.0 & 14.6 & 6.5 \\
\hline$>20.0$ & 83.2 & 39.1 & 15.6 & 12.6 & 21.5 & 57.7 & 87.3 & 77.3 & 76.8 & 39.8 & 36.4 & 33.1 & 16.9 & 20.4 & 14.3 \\
\hline \multicolumn{16}{|c|}{ Autumn } \\
\hline$-5.0-5.0$ & 13.0 & 26.6 & 30.2 & 41.0 & 26.4 & 15.3 & 12.0 & 14.9 & 10.0 & 22.7 & 26.7 & 29.6 & 30.9 & 25.3 & 42.2 \\
\hline$-5.1--20.0$ & 11.8 & 32.0 & 27.6 & 22.2 & 34.4 & 9.4 & 8.0 & 9.9 & 6.6 & 27.5 & 34.1 & 20.8 & 21.5 & 32.7 & 31.2 \\
\hline $5.1-20.0$ & 32.2 & 24.3 & 24.8 & 31.3 & 20.0 & 30.4 & 34.7 & 37.1 & 32.9 & 26.5 & 23.4 & 31.5 & 34.0 & 23.2 & 20.7 \\
\hline$<-20.0$ & 3.2 & 7.6 & 11.7 & 3.0 & 13.0 & 1.9 & 2.0 & 3.2 & 1.9 & 9.2 & 8.6 & 7.1 & 4.0 & 9.8 & 3.1 \\
\hline$>20.0$ & 39.8 & 9.5 & 5.7 & 2.5 & 6.2 & 43.0 & 43.2 & 34.9 & 48.5 & 14.1 & 7.2 & 11.0 & 9.6 & 9.0 & 2.7 \\
\hline
\end{tabular}

$\rightarrow$ indicates direction of travel 


\section{DISCUSSION}

Many research deals with specificity of bioclimatic conditions in particular locations. The analysis are usually made from the point of view of tourism (Blazejczyk 2007 a; Dubaniewicz et al., 1988, 1989), recreation (Blazejczyk, 2007 b; Bogucki ed. 1999) and health resorts (Kozłowska-Szczęsna et al., 2002). We can also find several papers trying to compare different regions and/or stations (Błażejczyk 2003, 2004; Kozłowska-Szczęsna et al., 1997, Krawczyk, 1993, 2001). However, the authors used various indices as well as the comparative studies have usually qualitative character.

$B C I$ is the first attempt to made quantitative analysis of compared locations. The results obtained confirm individual character of particular bioclimatic regions of Poland. BCI very well underline bioclimatic specificity of mountain and coastal regions. Significantly different are also North-East and South-East regions of Poland.

The mathematical formulation of $B C I$ make possible to use it not only for general spatial analysis of bioclimate. It can be also applied to define possible bioclimatic contrasts in particular days as well as in weather forecasts. It seems that temporal variability of bioclimatic conditions can be studied as well. Taking into consideration the results presented in the paper it can be stated, that $B C I$ index is an objective measure in studies dealing with the spatial contrasts of bioclimatic conditions.

\section{REFERENCES}

Beaumont van W., Bullard R.W., 1965, Sweating: Direct influence of skin temperature. Science, $147,3664,1465-1467$.

Blanc le J., 1975, Man in the cold. Ch.C.Thomas Publ., Springfield.

Błażejczyk K., 2001, Bilans cieplny człowieka jako narzędzie badań bioklimatycznych. [Human heat balance as a tool in bioclimatic research]. Przeglad Geograficzny, 73, 4, 535-554.

Błażejczyk K., 2003, Biotermiczne cechy klimatu Polski [Biothermal features of the climate of Poland], Przeglad Geograficzny, 75, 4, 525-543.

Błażejczyk K., 2004, Bioklimatyczne uwarunkowania rekreacji i turystyki w Polsce [Bioclimatic conditions of recreation and tourism in Poland], Prace Geograficzne IGiPZ PAN, 192, 291.

Blazejczyk K., 2007, Multiannual and seasonal weather fluctuations and tourism in Poland. [in:] B. Amelung, K. Blazejczyk, A. Matzarakis (eds.), Climate Change and Tourism Assessment and Copying Strategies, Maastricht-Warsaw-Freiburg, 69-90.

Błażejczyk K., Broede P., Fiala D., Havenith G., Holmér I., Jendritzky G., Kampmann B., Kunert A., 2010, Principles of the new Universal Thermal Climate Index (UTCI) and its application to bioclimatic research in European scale. Miscellanea Geographica, 14, 91-102.

Błażejczyk K., Epstein Y., Jendritzky G., Staiger H., Tinz B., 2011, Comparision of UTCI to selected thermal indices. International Journal of Biometeorology, DOI 10.1007/s00484-011-0453-2.

Błażejczyk K., Matzarakis A., 2007, Assessment of bioclimatic differentiation of Poland based on the human heat balance. Geographia Polonica, 80, 1, 63-82.

Błażejczyk K., Szyguła Z., 2004, Wpływ gorącego otoczenia na zdolność wysiłkową sportowca. Jak przygotować zawodnika do startu w Igrzyskach Olimpijskich w Atenach? [Influence of hot environment on physical efficiency during Olympic Games in Athens]. Sport Wyczynowy, $42,5 / 6,45-63$. 
Bogucki J. (ed.), 1999, Biometeorologia turystyki i rekreacji [Biometeorology of recreation and tourism]. AWF, Poznań.

Bröde P., Fiala D., Blazejczyk K., Holmér I., Jendritzky G., Kampmann B., Tinz B., Havenith G., 2011, Deriving the Operational Procedure for the Universal Thermal Climate Index UTCI. Int J Biometeorol, DOI 10.1007/s00484-011-0454-1.

Burton A.C., Edholm O.G., 1955, Man in a cold environment. E.Arnold Publ., London.

Clark R.P., Edholm O.G., 1985, Man and his thermal environment. E. Arnold Ltd., London.

Dubaniewicz H., Nurek T., Zawadzka A., 1988, Biometeorologia turystyki, Wybrane zagadnienia $z$ biometeorologii człowieka, cz. I. [Biometeorology of tourism, part I], AWF, Gdańsk.

Dubaniewicz H., Nurek T., Zawadzka A., 1989, Biometeorologia turystyki, Wybrane zagadnienia $z$ biometeorologii człowieka, cz. II. [Biometeorology of tourism, part II].AWF, Gdańsk.

Fiala D., Lomas K.J., Stohrer M., 1999, A computer model of human thermoregulation for a wide range of environmental conditions: The passive system. Journal of Applied Physiology, 87 (5), 1957-1972.

Fiala D., Lomas K.J., Stohrer M., 2001, Computer prediction of human thermoregulatory and temperature responses to a wide range of environmental conditions. International Journal of Biometeorology, 45, 143-159.

Fourt J., Hollies N.R.S., 1970, Clothing. Comfort and function. M. Dekker Inc., New York.

Freitas de C.R., Grigorieva E.A., 2009, The Acclimatization Thermal Strain Index (ATSI): a preliminary study of the methodology applied to climatic conditions of the Russian Far East. International Journal of Biometeorology 53, 307-315.

Freitas de C.R., Grigorieva E.A., 2010, Prediction of acclimatization thermal loading for individuals travelling between climatic extremes. [in:] Matzarakis A., Mayer H., Chmielewski F.-M. (eds.), Proceedings of the 7th Conference on Biometeorology. Berichte der Meteorologische Institut, Universität Freiburg, 20, 364-369.

Garden J.W., Wilson I.D., Rasch P.J., 1966, Acclimatization of healthy young adult males to a hot-wet environment. Journal of Applied Physiology, 21, 2, 665-669.

Givoni B., Goldman R.F., 1973, Predicting effects of heat acclimatization on heart rate and rectal temperature. Journal of Applied Physiology, 35, 6, 875-879.

Holmér I., 1988, Assessment of cold stress in terms of required clothing insulation - IREQ. International Journal of Industrial Ergonomics, 3, 159-166.

ISO/DC 11079, Evaluation of cold environments. Determination of required clothing insulation. International Organisation of Standardization, Geneva.

Jendritzky G., Dear de R., 2008: Adaptation and the Thermal Environment. [in:] Ebi K.L., Burton I., McGregor G. (eds.) Biometeorology for Adaptation to Climate Variability and Change: Research Frontiers and Perspectives. Springer, Heidelberg. 9-32.

Kenney W.L., 1985, A review of comparative responses of men and women to heat stress. Environmental Research, 37, 1, 1-11.

Kozłowska-Szczęsna T., Błażejczyk K., Krawczyk B., 1997, Bioklimatologia człowieka. Metody $i$ ich zastosowania $w$ badaniach bioklimatu Polski [Human bioclimatology. Methods and applications in research on the bioclimate of Poland], Monografie 1, Instytut Geografii i Przestrzennego Zagospodarowania, PAN.

Krawczyk B., 1993, Typologia i ocena bioklimatu Polski na podstawie bilansu cieplnego ciała człowieka [Typology and evaluation of Poland's bioclimate based on human heat balance], Prace Geograficzne, Instytut Geografii i Przestrzennego Zagospodarowania (IGiPZ), PAN, 160p.

Krawczyk B., 2001, Ryzyko wystapienia stresu ciepła w wybranych uzdrowiskach polskich [Hazard of heat stress in selected Polish health resorts], Balneologia Polska, 43, 1-2: 88-93.

Mateeva Z., Filipov A., 2003, Bioclimatic distance index in the Rila and Rhodopy area of Bulgaria. [in:] Błażejczyk K., Krawczyk B., Kuchcik M. (eds.), Postępy w badaniach klimatycznych i bioklimatycznych. Prace Geograficzne IGiPZ PAN, 188, 295-302.

Parsons K.C., 2003, Human thermal environments: the effects of hot, moderate, and cold environments on human health, comfort and performance. - Taylor \& Francis, London, New York, pp. 527

Rusanov, V., 1989, Appraisal of Meteorological Conditions defining Human Respiration. Bull. Rus. Academy of Medical Sciences, 1, 57-60. 


\section{ANNEX 1 \\ EXPLANATIONS OF VARIABLES USED FOR THE CALCULATIONS}

$\mathrm{d} M r t$ - difference between mean radiant temperature and air temperature $\left({ }^{\circ} \mathrm{C}\right)$, $E C I_{\mathrm{d}}-$ effective clothing insulation at destination (clo),

$E C I_{\mathrm{h}}$ - effective clothing insulation at home location (clo),

$f$ - relative humidity of air (\%),

$h c=(0.013 \cdot p-0.04 \cdot t-0.503) \cdot(v+1.1)^{0.4}$

$h c^{\prime}=(0.013 \cdot p-0.04 \cdot t-0.503) \cdot 0.53 /\left\{I c l \cdot\left[1-0.27 \cdot(v+1.1)^{0.4}\right]\right\}$

$h e=[t \cdot(0.00006 \cdot t-0.00002 \cdot p+0.011)+0.02 \cdot p-0.773)] \cdot 0.53 /$

$\left\{\right.$ Icl $\left.\cdot\left[1-0.27 \cdot(v+1.1)^{0.4}\right]\right\}$,

Icl - clothing insulation (clo),

$I c l p_{d}$ - predicted clothing insulation at chosen destination (clo),

$I c l p_{h}-$ predicted clothing insulation at home location (clo),

$I e=h c^{\prime} /\left(h c^{\prime}+h c\right)$,

$i M r t$ - mean radiant temperature under clothing $\left({ }^{\circ} \mathrm{C}\right)$ (for detail calculating procedures see: www.igipz.pan.pl/geoekoklimat/blaz/MENEX_2005.pdf),

$M r t-$ mean radiant temperature $\left({ }^{\circ} \mathrm{C}\right)$,

$M r t=\left[(R+0.5 \cdot \operatorname{Lg}+0.5 \cdot L a) /\left(s_{h} \cdot s\right)\right]^{0.25}-273$ (for detail calculating procedures see: www.igipz.pan.pl/geoekoklimat/blaz/MENEX_2005.pdf),

$P S T_{d}$ - physiological subjective temperature at chosen destination $\left({ }^{\circ} \mathrm{C}\right)$,

$P S T_{h}$ - physiological subjective temperature at home location $\left({ }^{\circ} \mathrm{C}\right)$,

Res $=0.189 \cdot(t-35)+2.336 \cdot(0.1 \cdot v p-5.624)$,

$\operatorname{Res}_{\mathrm{d}}$ - heat loss by respiration at studied destination,

$R e s_{\mathrm{h}}$ - heat loss by respiration at home location,

$s_{h}$ - emissivity coefficient for human body $(=0.95)$,

$\mathrm{Sr}$ - resultant value of net heat storage $\left(\mathrm{W} / \mathrm{m}^{2}\right)$ after $20 \mathrm{~min}$ of adaptation (for detail calculating procedures see: www.igipz.pan.pl/geoekoklimat/blaz/ MENEX_2005.pdf),

$S W_{d}$ - water loss at chosen destination $(\mathrm{g} / \mathrm{l})$,

$S W_{h}$ - water loss at home location $(\mathrm{g} / \mathrm{l})$,

$t$ - air temperature $\left({ }^{\circ} \mathrm{C}\right)$,

Ts - skin temperature $\left({ }^{\circ} \mathrm{C}\right)$,

$T s=(26.4+0.02138 \cdot M r t+0.2095 \cdot t-0.0185 \cdot f-0.009 \cdot v)+0.6 \cdot(I c l-1)+0.1728$,

$U T C I_{d}-$ heat stress at chosen destination $\left({ }^{\circ} \mathrm{C}\right)$,

$U T C I_{h}$ - heat stress at home location $\left({ }^{\circ} \mathrm{C}\right)$,

$v$ - wind speed at $1.2 \mathrm{~m}(\mathrm{~m} / \mathrm{s})$,

$v p$ - actual air vapour pressure $(\mathrm{hPa})$,

$v p_{5}-$ air vapour pressure $(\mathrm{hPa})$ at actual air temperature and relative humidity of $5 \%$, $v p_{s k}-$ saturated vapour pressure $(\mathrm{hPa})$ at actual skin temperature, $w-$ skin wettedness,

$w=1.031 /(37.5-T s)-0.065,\left(\right.$ at $T s>36.5^{\circ} \mathrm{C} w=1.0$ and at $\left.T s<22^{\circ} \mathrm{C} w=0.001\right)$, www.igipz.pan.pl/geoekoklimat/blaz/MENEX_2005.pdf)

$s$ - Stefan-Boltzman constant $\left(=5.667 \cdot 10^{-8}, \mathrm{~W} \cdot \mathrm{m}^{2} \cdot \mathrm{K}^{-4}\right)$ 